\title{
Pengaruh Suhu dan Lama Penyimpanan ASI terhadap Kadar Laktoferin dan Lisozim yang Terkandung di dalam ASI
}

\author{
Nanda Wahyudi ${ }^{1}$, Arni Amir ${ }^{2}$, Eny Yantri ${ }^{3}$
}

\begin{abstract}
Abstrak
Nutrisi ASI penting bagi pertumbuhan dan perkembangan bayi. Kesibukan pekerjaan menyebabkan ibu harus memerah dan menyimpan ASI untuk diberikan kepada bayi saat ibu jauh dari bayinya. Penelitian ini bertujuan mengetahui pengaruh suhu dan lama penyimpanan ASI terhadap kadar laktoferin dan lisozim yang terkandung di dalam ASI. Penelitian ini eksperimental murni dengan one group pretest-posttest design. Dilakukan di Puskesmas Seberang Padang, BPM Nurhaida, Klinik Meri Medika, BPM Rika Hardi dan laboratorium Pusat Diagnostik dan Riset Penyakit Infeksi Bagian Mikrobiologi Fakultas Kedokteran Universitas Andalas pada bulan Juni 2017 - Juli 2018. Sampel berjumlah 20 ASI ibu menyusui 4-10 hari postpartum. Kadar laktoferin dan lisozim diperiksa dengan ELISA. Uji normalitas data menggunakan Kolmogorov-smirnov. Uji bivariat menggunakan One-way Anova dan Kruskal-wallis. Uji multivariat menggunakan regresi linier berganda. Hasil penelitian menunjukkan terdapat perbedaan kadar laktoferin yang bermakna antara ASI segar, suhu $4^{\circ} \mathrm{C}$ dan $-20^{\circ} \mathrm{C}(p=0,000)$, serta antara ASI Segar, penyimpanan 5 hari dan 28 hari $(p=0,000)$. Terdapat perbedaan lisozim yang bermakna antara ASI segar, suhu $4^{\circ} \mathrm{C}$ dengan $-20^{\circ} \mathrm{C}(p=0,000)$, serta antara ASI segar, penyimpanan 5 hari dan 28 hari $(p=0,000)$. Uji multivariat menunjukkan lama penyimpanan berpengaruh lebih besar terhadap kadar laktoferin. Kesimpulan penelitian ini adalah kadar laktoferin ASI stabil dengan penyimpanan pada suhu $-20^{\circ} \mathrm{C}$ selama 5 hari. Kadar lisozim ASI meningkat dengan penyimpanan pada suhu $-20^{\circ} \mathrm{C}$ selama 5 hari.
\end{abstract}

Kata Kunci: ASI, Suhu, Lama Penyimpanan, Lisozim, Laktoferin

\begin{abstract}
ASI nutrition is important for baby's growth and development. Busy work causes the mother to be reddened and store breast milk to give to the baby when the mother is far from the baby. This study aims to determine the effect of temperature and duration of ASI storage on levels of lactoferrin and lysozyme contained in ASI. This research is pure experimental with one group pretest-posttest design. It was conducted at the Seberang Padang Health Center, BPM Nurhaida, Meri Medika Clinic, Rika Hardi BPM and the Laboratory of Diagnostic and Research Center for Infectious Microbiology Section of the Faculty of Medicine, Andalas University in June 2017 - July 2018. The sample consisted of 20 breast milk mothers breastfeeding 4-10 days postpartum. Lactoferrin and lysozyme levels were examined by ELISA. Test the normality of the data using Kolmogorov-smirnov. Bivariate test using One-way Anova and Kruskal-wallis. Multivariate test uses multiple linear regression. The results showed that there were significant differences in lactoferrin levels between fresh breast milk, $4^{\circ} \mathrm{C}$ and $-20^{\circ} \mathrm{C}(p=0.000)$, and between Fresh ASI, storage 5 days and 28 days $(p=0.000)$. There was a significant difference in lysozyme between fresh breast milk, $4^{\circ} \mathrm{C}$ with $20^{\circ} \mathrm{C}(p=0,000)$, and between fresh breast milk, storage 5 days and 28 days $(p=0,000)$. Multivariate tests show that storage time has a greater effect on lactoferrin levels. The conclusion of this study is that the levels of breast milk lactoferrin are stable with storage at $-20^{\circ} \mathrm{C}$ for 5 days. ASI lysozyme levels increase with storage at $-20^{\circ} \mathrm{C}$ for 5 days.
\end{abstract}

Keywords: breast milk, temperature, storage time, lysozyme

1. Prodi Magister S2 IImu Kebidanan Fakultas Kedokteran Universitas Andalas (FK Unand), 2. Bagian Biologi FK Unand, 3. Dokter Spesialis Anak Sub Bagian Neonatologi bagian IKA FK Unand/RS Dr. M. Djamil Affiliasi penulis :

Korespondensi : Arial 7 nandawahyudiapril@gmal.com Telp: 085266770305

\section{PENDAHULUAN}

ASI mengandung sel-sel darah putih, immunoglobulin, enzim dan hormon, serta protein spesifik, dan zat gizi lainnya yang diperlukan untuk pertumbuhan dan perkembangan anak. ${ }^{1}$ Pemberian ASI tanpa tambahan bahan makanan lain dapat mencukupi kebutuhan pertumbuhan bayi sampai berusia 6 bulan. Setelah bayi berusia 6 bulan diberikan tambahan Makanan Pendamping ASI
(MP-ASI) dan pemberian ASI dilanjutkan sampai dengan usia 2 tahun. $^{2}$

Pada kondisi tertentu bayi tidak dpt menyusui langsung dengan ibunya seperti ibu yang bekerja ${ }^{2}$ dan bayi sakit yang harus dirawat diruang Neonatal Intensive Care Uni (NICU). ${ }^{3}$ Sebelum diberikan kepada bayi, ASI yang telah diperah biasanya akan diangkut dari tempat ibu menuju ke ruang NICU. Bila bayi belum akan menyusui maka ASI yang telah diperah akan disimpan terlebih dahulu di lemari pendingin yang ada di ruang NICU. ${ }^{3}$

Di antara kandungan nutrisi yang ada di dalam ASI, terdapat laktoferin yang merupakan protein yang bermanfaat bagi kesehatan bayi. Laktoferin adalah glikoprotein dengan berat molekul $80 \mathrm{kDa}$, terdiri dari sekitar 690 residu asam amino yang 
memiliki fungsi kekebalan dan berbagai aktivitas biologis. ${ }^{4}$ Nutrisi lain pada ASI yang dapat dipengaruhi oleh penyimpanan ASI adalah lisozim. Lisozim adalah enzim aktif yang hadir sebanyak 3000 kali lipat lebih tinggi kandungannya pada ASI dibandingkan susu sapi dan berfungsi sebagai enzim antibakteri. Lisozim mampu menghancurkan dinding luar bakteri Gram positif dengan cara menghidrolisis ikatan $\beta-1,4$ dari residu asam $\mathrm{N}$-asetilmuramat dan $\mathrm{N}$-asetilglukosamin bakteri. $^{5}$

Penyimpanan ASI untuk sejumlah waktu dan suhu dapat berdampak pada konsentrasi nutrisi ASI. ${ }^{6}$ Penyimpanan ASI beku selama 4 minggu pada suhu $-20^{\circ} \mathrm{C}$ mengurangi aktivitas komponen imunologi ASI seperti lisozom, imunoglobulin A, laktroperoksidase, muramidase, laktoferin, dan peroksidase. Pengurangan aktivitas komponen ASI ini dapat dikaitkan dengan peningkatan kemampuan proliferasi bakteri. Rollo et al. (2014) menyelidiki dampak penyimpanan ASI terhadap konsentrasi laktoferin pada suhu $18^{\circ} \mathrm{C}$ dan $20^{\circ} \mathrm{C}$ selama 3 dan 6 bulan. Hasil penelitian ini menunjukkan hilangnya laktoferin terbesar terjadi karena aktivitas awal pembekuan dan terus berlanjut selama 6 bulan penyimpanan. Hasil penelitian ini menunjukkan bahwa setiap penyimpanan dengan suhu rendah memiliki dampak buruk pada fungsi imunologis ASI. Berbagai proses pembekuan maupun pasteurisasi pada ASI dapat mempengaruhi konsentrasi protein imunomodulator, terutama laktoferin, immunoglobulin $A$, dan lisozim. Protein immunoaktif seperti laktoferin, IgA, dan lisozim, rentan terhadap beberapa degradasi karena pembekuan untuk waktu yang lama. ${ }^{7}$

Penelitian yang dilakukan oleh Akinbi et al. (2010) didapatkan bahwa ASI yang disimpan pada suhu $-20^{\circ} \mathrm{C}$ selama 4 minggu akan mengalami penurunan kadar lisozim $32 \%$ dibandingkan dengan ASI segar $(p<0,001) .{ }^{8}$ Hasil yang sama juga dilaporkan oleh Chang et al. (2013). Berdasarkan hasil penelitiannya kadar lisozim mengalami penurunan signifikan 39\% lebih rendah dibandingkan dengan ASI segar bila disimpan selama 4 minggu pada suhu $20^{\circ} \mathrm{C}$ $(p<0,0001)$ dan kadar laktoferin lebih rendah $11,5 \%$ dibandingkan ASI segar. ${ }^{9}$

Oleh karena itu, penelitian ini dilakukan untuk mengetahui pengaruh suhu dan lama penyimpanan terhadap kadar laktoferin dan lisozim yang terkandung di dalam ASI.

\section{METODE}

Penelitian ini dilakukan di Wilayah kerja Puskesmas Seberang Padang, Puskesmas Andalas Padang (BPM Nurhaida), Puskesmas Kuranji Padang (Klinik Meri Medika) dan Puskesmas Ambacang Padang (Bidan Rika Hardi). Penelitian ini merupakan eksperimental murni dengan menggunakan desain One Group Pretest-Posttest Design. Populasi dalam penelitian ini adalah ASI yang didapatkan dari ibu-ibu menyusui yang berada di Wilayah kerja Puskesmas Seberang Padang, Puskesmas Andalas Padang (BPM
Nurhaida), Puskesmas Kuranji Padang (Klinik Meri Medika) dan Puskesmas Ambacang Padang (Bidan Rika Hardi).

Sampel pada penelitian ini adalah bagian dari populasi yang memenuhi kriteria inklusi dan ekslusi. Kriteria Inklusi. Ibu bersedia menjadi subyek penelitian. Ibu dan bayi dalam keadaan sehat. ASI yang didapatkan dari ibu yang memiliki bayi berusia 4 sampai 10 hari. ASI yang didapatkan dari ibu yang memiliki bayi yang lahir cukup bulan. Kriteria Eksklusi. Ibu yang mengonsumsi obat antibiotik.

Berdasarkan perhitungan tersebut, maka jumlah sampel minimal yang diperlukan adalah 20 . Teknik pengambilan sampel pada penelitian ini dilakukan dengan metode simple random sampling. Pengambilan sampel ini dilakukan dengan cara acak sederhana dari jumlah populasi yang ada. Sampel diambil dengan melakukan pengundian. Setelah dilakukan pengundian, maka akan terpilih 20 orang yang akan menjadi sampel pada penelitian ini. 20 Sampel dilakukan pengukuran pada 0 hari (ASI segar), penyimpanan 5 hari dan penyimpanan 28 hari pada suhu $\mathrm{ASI}$ segar, $4^{\circ} \mathrm{C}$ dan $-20^{\circ} \mathrm{C}$, sehingga sampel yang akan diperiksa kadar laktoferin dan lisozimnya adalah 240 sampel ASI.

Pemeriksaan kadar lektoferin dan lisozim menggunakan Metode ELISA penelitian ini telah mendapatkan persetujuan etik dari panitia Kode Etik penelitian di fakultas kedokteran Universitas Andalas. Data laktoferin dan lisozim yang diperoleh dianalisis dengan uji Anova dan kruskal wallis.

\section{HASIL}

Tabel 1. Uji One-Way Anova Pengaruh Suhu dan Lama Penyimpanan ASI terhadap Kadar Laktoferin yang Terkandung di dalam ASI

\begin{tabular}{|r|c|c|c|}
\hline \multirow{2}{*}{ Suhu } & \multicolumn{3}{|c|}{ Lama Penyimpanan } \\
\cline { 2 - 4 } & Hari Ke-0 & Hari Ke-5 & Hari Ke-28 \\
\hline$-20^{\circ} \mathrm{C}$ & $80,55 \pm 14,23$ & $81,09 \pm 9,25$ & $21,45 \pm 3,67$ \\
& & & \\
4 & & \\
& $80,55 \pm 14,23$ & $68,37 \pm 8,26$ & $17,17 \pm 4,34$ \\
\hline
\end{tabular}

Tabel 1. menunjukkan bahwa terdapat pengaruh suhu dan lama penyimpanan ASI terhadap kadar laktoferin yang terkandung di dalam ASI. Kadar laktoferin $\mathrm{ASI}$ yang disimpan selama 5 hari pada kelompok suhu $20^{\circ} \mathrm{C}$ meningkat dibandingkan ASI segar, sedangkan pada kelompok suhu $4^{\circ} \mathrm{C}$ menurun dibandingkan ASI segar. Perbedaan ini bermakna secara statistik dengan nilai $p=0,001$. Kadar laktoferin ASI yang disimpan selama 28 hari pada kelompok suhu $20^{\circ} \mathrm{C}$ menurun dibandingkan ASI segar, begitu juga pada kelompok suhu $4^{\circ} \mathrm{C}$ menurun dibandingkan ASI segar. Perbedaan ini bermakna secara statistik dengan nilai $p=0,000$. Kadar laktoferin ASI yang disimpan di suhu $-20^{\circ} \mathrm{C}$ selama penyimpanan 5 hari meningkat dibandingkan ASI segar, sedangkan penyimpanan 28 hari menurun dibandingkan ASI segar. Perbedaan ini bermakna secara statistik dengan nilai $p=0,000$. Kadar laktoferin ASI yang disimpan di suhu $4^{\circ} \mathrm{C}$ selama penyimpanan 5 hari 
menurun dibandingkan ASI segar, begitu juga penyimpanan 28 hari menurun dibandingkan ASI segar. Secara statistik diperoleh nilai $p=0,000$ yang berarti terdapat perbedaan yang bermakna kadar laktoferin $\mathrm{ASI}$ yang disimpan di suhu $4^{\circ} \mathrm{C}$ antara kelompok ASI segar, penyimpanan 5 hari dan penyimpanan 28 hari.

Analisa multivariat menggunakan regresi liner berganda menunjukkan bahwa lama penyimpanan ASI berpengaruh lebih besar terhadap perubahan kadar laktoferin pada ASI yang disimpan.

Tabel 2. Uji One-Way Anova Pengaruh Suhu terhadap Kadar Lisozim yang Terkandung di dalam ASI

\begin{tabular}{|l|c|c|c|}
\hline \multirow{2}{*}{ Suhu } & \multicolumn{3}{|c|}{ Lama Penyimpanan } \\
\cline { 2 - 4 } & Hari Ke-0 & Hari Ke-5 & Hari Ke-28 \\
\hline$-20^{\circ} \mathrm{C}$ & 17,98 & 36,74 & 10,38 \\
& $(3,77-34,82)$ & $(13,09-65,39)$ & $(1,48-27,38)$ \\
\multirow{2}{*}{$4^{\circ} \mathrm{C}$} & 17,982 & 5,68 & 2,34 \\
& $(3,77-34,82)$ & $(4,20-42,11)$ & $(0,69-28,18)$ \\
\hline
\end{tabular}

Tabel 2. memperlihatkan bahwa terdapat pengaruh suhu dan lama penyimpanan ASI terhadap kadar lisozim yang terkandung di dalam ASI. Kadar lisozim ASI yang disimpan selama 5 hari pada kelompok suhu $20^{\circ} \mathrm{C}$ meningkat dibandingkan ASI segar, sedangkan kadar lisozim pada kelompok suhu $4^{\circ} \mathrm{C}$ menurun dibandingkan ASI segar. Perbedaan ini bermakna secara statistik dengan nilai $p=0,000$. Kadar lisozim ASI yang disimpan selama 28 hari pada kelompok suhu $20^{\circ} \mathrm{C}$ menurun dibandingkan ASI segar, begitu juga kadar lisozim pada kelompok suhu $4^{\circ} \mathrm{C}$ menurun dibandingkan ASI segar. Perbedaan ini bermakna secara statistik dengan nilai $p=0,000$. Kadar lisozim ASI yang disimpan di suhu $20^{\circ} \mathrm{C}$ selama penyimpanan 5 hari meningkat dibandingkan ASI segar, sedangkan penyimpanan 28 hari menurun dibandingkan ASI segar. Perbedaan ini bermakna secara statistik dengan nilai $p=0,000$. Kadar lisozim ASI yang disimpan di suhu $4^{\circ} \mathrm{C}$ selama penyimpanan 5 hari menurun dibandingkan ASI segar, begitu juga pada penyimpanan 28 hari menurun dibandingkan ASI segar. Perbedaan ini bermakna secara statistik dengan nilai $p=0,000$.

\section{PEMBAHASAN}

\section{Pengaruh Suhu dan Lama Penyimpanan ASI terhadap Kadar Laktoferin yang Terkandung di dalam ASI}

Penelitian ini menunjukkan bahwa penyimpanan $\mathrm{ASI}$ pada suhu dingin $\left(4^{\circ} \mathrm{C}\right)$ dan beku $\left(-20^{\circ} \mathrm{C}\right)$ jangka pendek yaitu 5 hari dapat mengurangi kadar laktoferin dan akan terus mengalami degradasi hingga penyimpanan selama 28 hari.

Suhu sangat mempengaruhi stabilitas nutrisi yang ada di dalam ASI yang disimpan. Pada suhu refrigerasi yaitu antara suhu $2-8^{\circ} \mathrm{C}$ hanya dapat memperlambat degradasi nutrisi ASI dan membatasi pertumbuhan mikroba untuk waktu yang singkat saja. Pada suhu dingin (refrigerasi) dapat berkembang mikroba yang dikatakan sebagai psikotropik, umumnya nonpatogen, tetapi dapat merusak ASI selama penyimpanan jangka waktu yang lama. ${ }^{10}$

Pendinginan juga akan memperlambat tanpa menghilangkan beberapa aktivitas enzimatik, misalnya lipase, oxidase, protease yang terus bereaksi pelanpelan dan akhirnya kita akan melihat proses autolisis dari protein (proteolisis). Proses autolisis ini terjadi sebagai suatu hal tambahan kejadian selain proses ketengikan bahan lemak selama penyimpanan dingin yang menimbulkan bau. Autolisis protein ini diikuti oleh proses decarboxylation dari asam amino yang mengarah pada pembentukan amina yang toksin (beracun), seperti putrescine, cadaverine, dan hitamine yang bisa menyebabkan alergi pada individu tertentu. Proteolisis juga dapat menaikkan kadar asam amino bebas pada ASI. Asam amino bebas bisa menyebabkan rasa pahit. ${ }^{11}$

Pengaruh utama pembekuan terhadap kualitas bahan pangan adalah kerusakan sel yang diakibatkan oleh pertumbuhan kristal es. Pembekuan menyebabkan perubahan-perubahan yang kecil pada pigmen, cita rasa atau komponen-komponen nutrisi penting. Tingkat kerusakan bergantung pada ukuran kristal es dan laju pindah panas. Proses laju pembekuan lambat menyebabkan kristal es tumbuh pada ruang antar sel, yang menyebabkan perubahan bentuk (deformasi) dan kerusakan dinding sel di dekatnya. Kristal es mempunyai tekanan uap air yang lebih rendah di dalam sel sehingga air berpindah dari dalam sel menuju kristal yang sedang tumbuh, akibatnya sel mengalami dehidrasi dan secara permanen mengalami kerusakan akibat peningkatan konsentrasi solut. Kerusakan juga dapat terjadi pada proses thawing (pencairan), sel yang rusak tidak kembali ke wujud asalnya. ${ }^{12}$

Pada penelitian ini penyimpanan ASI pada suhu $-20^{\circ} \mathrm{C}$ lebih baik daripada suhu $4^{\circ} \mathrm{C}$. Suhu penyimpanan ASI yang lebih hangat dikaitkan dengan jumlah mikrobiota yang tumbuh lebih cepat. ASI yang diperah dapat mengandung mikrobiota yang berasal dari kulit ibu dan duktus puting payudara, terkadang juga dapat mengandung patogen potensial. Oleh sebab itu kontaminasi bakteri pada saat pemerahan ASI sebaiknya dihindari. ${ }^{11}$

Selama ASI disimpan di dalam lemari pendingin, mikrobiota yang ada di dalam ASI melakukan metabolisme untuk menghasilkan energi yang berguna untuk kelangsungan hidup mikrobiota. Proses metabolisme mikrobiota ini memerlukan nutrisi yang berasal dari lingkungannya dalam hal ini adalah protein, lemak dan karbohidrat. Nutrisi ASI yang kaya akan karbohidrat, protein, lemak yang merupakan medium dalam pertumbuhan mikrobiota. Bakteri akan mengeluarkan enzim protease, lipase dan betagalaktosidase untuk mencerna nutrisi pada ASI. Enzim lipase, protease dan dekarboksilase yang dihasilkan oleh beberapa bakteri di dalam ASI yang disimpan dapat menyebabkan kerusakan protein anti-mikroba atau mengubah asam amino bebas menjadi amina 
toksik. Laktoferin merupakan komponen bioaktif tersusun oleh protein. Pada penyimpanan ASI, laktoferin digunakan oleh mikrobiota dalam proses metabolisme sehingga selama penyimpanan kadar laktoferin akan berkurang. ${ }^{10}$

Bakteri asam laktat (BAL) pada ASI mampu memecah glukosa yang terdapat pada ASI sehingga terbentuk asam laktat. Adanya akumulasi asam laktat pada ASI menyebabkan nilai $\mathrm{pH}$ ASI menurun, sehingga ASI akan menggumpal. Gumpalan ASI akan mulai terbentuk pada $\mathrm{pH} \mathrm{5,2} \mathrm{dan} \mathrm{apabila} \mathrm{nilai} \mathrm{pH}$ telah mencapai 4,6 (merupakan titik isoelektrik), koagulasi protein ASI berlangsung sempurna dan akan terbentuk curd. ${ }^{10}$ Penurunan $\mathrm{pH}$ juga berakibat pada kesetimbangan protein yang memungkinkan protein terdenaturasi dan menyebabkan tekstur ASI menjadi lebih kental.

Temuan serupa dilaporkan oleh Chang et al. (2013), dimana pada penelitiannya ASI yang disimpan pada suhu $-20^{\circ} \mathrm{C}$ selama 4 minggu akan mengalami penurunan kadar laktoferin yang signifikan.9 Hasil serupa dilaporkan oleh Raoof et al. (2016) yang menemukan bahwa pembekuan pada suhu $-20^{\circ} \mathrm{C}$ dan penyimpanan jangka panjang dapat menurunkan konsentrasi laktoferin $\mathrm{ASI}^{13}$

Hasil penelitian ini memperlihatkan bahwa rerata kadar laktoferin antara ASI segar dengan ASI penyimpanan 5 hari menurun namun tidak signifikan. Hasil ini serupa dengan temuan Rollo et al. (2014) yang menyatakan bahwa pada ASI yang disimpan selama 5 hari pada suhu $4^{\circ} \mathrm{C}$ tidak mengalami penurunan kadar laktoferin yang signifikan. Slutzah et al. (2010) juga menemukan hasil penelitian yang serupa dimana kadar laktoferin tidak mengalami penurunan yang signifikan bila disimpan selama 4 hari pada suhu $4^{\circ} \mathrm{C}$. Stabilitas kadar laktoferin pada ASI yang disimpan selama 5 hari pada suhu $4^{\circ} \mathrm{C}$ ini disebabkan karena laktoferin merupakan komponen antimikroba yang berperan untuk menghambat perkembangan mikroba pembusuk dengan cara mencegah penggunaan zat besi dan karbohidrat lebih lanjut untuk proliferasi bakteri ASI. ${ }^{14}$

\section{Faktor Dominan yang Mempengaruhi Kadar Laktoferin}

Hasil penelitian ini menunjukkan bahwa lama penyimpanan ASI lebih mempengaruhi kadar laktoferin yang terkandung di dalam ASI. ASI merupakan bahan pangan yang tergolong mudah rusak. Kerusakan terjadi karena pencemaran yang berasal dari mikroba, kimia dan enzimatis. ${ }^{10}$ Penyimpanan ASI yang semakin lama akan menyebabkan mikroba yang ada di dalam ASI berkembangbiak dan semakin banyak. Mikroba ini menyebabkan pembusukan pada ASI sehingga kadar laktoferin semakin lama akan rusak dan berkurang. ${ }^{15}$

\section{Pengaruh Suhu dan Lama Penyimpanan ASI terhadap Kadar Lisozim yang Terkandung di dalam ASI}

Pada suhu pembekuan $-18^{\circ} \mathrm{C}$, terjadi penurunan mutu ASI yang lambat akibat perubahan kimia atau aktivitas enzim. Perubahan tersebut dipercepat dengan perubahan $\mathrm{pH}$, peningkatan konsentrasi solut disekitar es, penurunan aktivitas air, dan potensi reduksi-oksidasi. Jika enzim tidak diinaktivasi sebelum pembekuan, kerusakan membran sel menyebabkan enzim kontak dengan solut dan bereaksi sehingga menyebabkan penurunan kualitas ASI. ${ }^{12}$

ASI mengalami penurunan nilai $\mathrm{pH}$ seiring dengan lama penyimpanan ASI sampai hari ke-12. Perubahan $\mathrm{pH}$ (keasaman) dapat disebabkan oleh keberadaan bakteri yang terdapat pada ASI selama penyimpanan. $\mathrm{pH}$ ASI sekitar 7,01 , pada $\mathrm{pH}$ sekitar ini mikroba khusus bakteri asam laktat merofilik sangat cepat beradaptasi dan berkembang biak. Perubahan $\mathrm{pH}$ ASI dapat menurunkan kadar lisozim yang merupakan ensim pada ASI. ${ }^{16}$

Pada suhu dingin akan terjadi penurunan kualitas nutrisi pada ASI yang merupakan dampak dari pendinginan. Enzim lisozim akan terdenaturasi oleh karena perubahan suhu (pembekuan, dingin maupun panas), $\mathrm{pH}$, kadar air dan garam. Banyak enzim menunjukkan aktivitas yang nyata pada bahan setengah beku, yaitu yang sebagian telah beku dan sebagian belum membeku. Selama proses pembekuan, pada bagian yang belum membeku masih terdapat air. Disitulah terjadi pengumpulan dan pengentalan larutan-larutan, sehingga konsentrasi elektrolit meningkat, juga $\mathrm{pH}$ berubah, sehingga mengakibatkan terjadinya berbagai pengaruh buruk terhadap bahan makanan beku. ${ }^{17}$

Pada umumnya peningkatan konsentrasi larutan dalam air yang belum membeku dapat meningkatkan atau menurunkan keaktifan enzim. Di dalam sistem beku, terjadi larutan dengan viskositas tinggi dan dapat menghalangi difusi enzim dan substrat; akibatnya dapat membatasi aktivitas enzim, karena itu pembekuan cara lambat, dan juga thawing yang lambat akan lebih banyak menghilangkan aktivitas enzim daripada cara pembekuan dan thawing yang cepat. Beberapa enzim dapat dirusak apabila dibiarkan pada suhu rendah bukan beku (chilling). Keadaan tersebut dikenal dengan nama denaturasi dingin. Selain itu suhu dingin akan menyebabkan lisozim mengalami proteolisis dan menaikkan kadar asam amino bebasnya yang menyebabkan rasa pahit pada ASI. ${ }^{17}$

Lisozim merupakan enzim utama yang terdapat pada ASI memiliki efek antibakteri yang berguna bagi bayi. Struktur enzim lisozim adalah protein. Pada ASI yang telah disimpan dilemari pendingin, terjadi pertumbuhan bakteri asam laktat. Untuk mempertahankan hidupnya, bakteri asam laktat akan menggunakan nutrisi yang ada pada ASI yaitu protein, karbohidrat dan lemak. Hal ini akan berdampak pada 
turunnya kadar protein, lemak dan karbohidrat ASI serta penurunan kualitas gizi yang lainnya yang terkandung di dalam ASI. ${ }^{18}$

ASI mengandung bermacam-macam unsur dan sebagian besar terdiri dari zat makanan yang juga diperlukan bagi pertumbuhan bakteri. Oleh karenanya pertumbuhan bakteri dalam ASI sangat cepat pada suhu yang sesuai. ${ }^{18}$ ASI dapat mengandung mikroorganisme yang berasal dari lubang diujung puting yang tidak tertutup dan biasanya basah, dan telah diketahui bahwa bakteri dapat tumbuh sedikit agak jauh ke dalam puting. Ketika ASI ini diambil mikroorganisme ini terbawa dan dengan demikian menjadi sumber pencemaran yang lain lagi. ${ }^{15} \mathrm{ASI}$ juga mengandung bakteri nonpatogen yang berasal dari jalur endogen tubuh ibu. ${ }^{11}$

Tumbuhnya mikroorganisme dalam ASI dapat menimbulkan suatu kerugian dalam mutu ASI. Beberapa kerusakan pada ASI yang disebabkan karena tumbuhnya mikroorganisme antara lain adalah; pengasaman dan penggumpalan yang disebabkan karena fermentasi laktosa menjadi asam laktat yang menyebabkan turunnya $\mathrm{pH}$ dan juga dapat menyebabkan terjadinya penggumpalan casein; berlendir seperti tali yang disebabkan karena terjadinya pengentalan dan pembentukan lendir sebagai akibat pengeluaran bahan seperti kapsul dan bergetah oleh beberapa jenis bakteri; penggumpalan ASI yang timbul tanpa penurunan $\mathrm{pH}$. Hal ini disebabkan oleh bakteri yang menghasilkan enzim yang mencerna lapisan tipis fosfolipid di sekitar butirbutir lemak dan dengan demikian kemungkinan butirbutir itu menyatu membentuk suatu gumpalan yang timbul ke permukaan ASI. ${ }^{9}$

Data penelitian ini konsisten dengan hasil penelitian yang dilakukan oleh Akinbi et al. (2010) yang menemukan bahwa kadar lisozim menurun secara signifikan pada ASI yang disimpan selama 4 minggu pada suhu $-20^{\circ} \mathrm{C}$. Hasil penelitian ini menunjukkan stabilitas nutrisi ASI yang disimpan pada suhu beku $\left(20^{\circ} \mathrm{C}\right)$ lebih baik dibandingkan pada suhu dingin $\left(4^{\circ} \mathrm{C}\right)$. Selain lisozim, suhu dan lama penyimpanan ASI juga dapat mempengaruhi kualitas nutrisi ASI lainnya. ${ }^{8}$

Data penelitian ini menunjukkan kadar lisozim ASI yang disimpan pada suhu $-20^{\circ} \mathrm{C}$ tidak berbeda secara signifikan dibandingkan dengan ASI segar. Penyimpanan ASI pada suhu $-20^{\circ} \mathrm{C}$ menunjukkan ketahanan terhadap kerusakan kadar lisozim. Hal ini disebabkan oleh semakin rendah suhu penyimpanan ASI maka pertumbuhan mikroba semakin lambat. Sehingga bakteri yang menggunakan lisozim sebagai sumber energi lebih sedikit. ${ }^{19}$ Hasil penelitan ini serupa dengan penelitian yang dilakukan oleh Fogleman (2008) yang menemukan bahwa kadar lisozim menunjukkan stabilitas selama 3 minggu penyimpanan pada suhu $-20^{\circ} \mathrm{C}$. Meskipun proteolisis pada penyimpanan suhu $-20^{\circ} \mathrm{C}$ tetap berlangsung namun kadar lisozim tidak menurun. Hasil ini menunjukkan bahwa lisozim mampu bertahan terhadap proteolisis selama penyimpanan ASI. Lisozim juga dapat bertahan di lingkungan yang tidak bersahabat pada saluran pencernaan karena tahan terhadap degradasi dari protease seperti tripsin dan juga oleh asam diperut. Oleh karena itu tidak mengherankan bahwa aktivitas lisozim tetap stabil selama penyimpanan pada suhu $20^{\circ} \mathrm{C} .{ }^{20}$

Hasil penelitian ini memperlihatkan bahwa pada penyimpanan ASI 5 hari, kadar lisozim mengalami penurunan yang tidak signifikan dibandingkan ASI segar. Stabilitas kadar lisozim ini dikarenakan lisozim merupakan komponen antimikroba yang mampu menghambat perkembangan bakteri, ${ }^{21}$. Lisozim juga mampu bertahan dari proteolisis sehingga pada penyimpanan selama 5 hari lisozim tidak menunjukkan penurunan kadar yang signifikan. ${ }^{20}$

Penelitian ini dapat meningkatkan pengetahuan tentang dampak penyimpanan ASI selama 5 hari pada suhu $4^{\circ} \mathrm{C}$ yang merupakan batas penyimpanan ASI yang direkomendasikan oleh Ikatan Dokter Anak Indonesia. ${ }^{6}$

\section{SIMPULAN}

Kadar laktoferin ASI stabil dengan penyimpanan pada suhu $-20^{\circ} \mathrm{C}$ selama 5 hari. Kadar lisozim ASI meningkat dengan penyimpanan pada suhu $-20^{\circ} \mathrm{C}$ selama 5 hari

\section{SARAN}

Penyimpanan ASI selama 5 hari sebaiknya pada suhu $-20^{\circ} \mathrm{C}$ karena tidak menyebabkan penurunan kadar laktoferin maupun lisozim. Perlu penelitian lebih lanjut mengenai pengaruh penyimpanan ASI terhadap kadar laktoferin dan lisozim pada ASI yang disimpan pada suhu $-20^{\circ} \mathrm{C}$ selama penyimpanan antara 5 sampai 28 hari.

\section{DAFTAR PUSTAKA}

1. Maryunani A. Inisiasi Menyusu Dini, ASI Eksklusif dan Manajemen Laktasi. Jakarta: TIM; 2015. hlm $1-178$

2. Kementerian Kesehatan Republik Indonesia. Infodatin ASI. Mari Dukung Menyusui dan Bekerja. Jakarta: Kementerian Kesehatan RI. 2015. hlm 1-7

3. McArthur A, Peters MDJ, Munn Z, Wing HC. Evidence Check, Safe Management of Expressed Breast Milk (EBM). Sax Institute. 2014. hlm 1-28

4. Susana A. Chávez G, Sigifredo, Gallegos A, Quintín, Cruz R. Lactoferrin: structure, function and applications. International Journal of Antimicrobial Agents. 2009;33. hlm 301.e1-301.e8

5. Lonnerdal B. Bioactive proteins in breast milk. Journal of Paediatrics and Child Health. 2013;49(1). hlm 1-7

6. Ikatan Dokter Anak Indonesia (IDAI). Penyimpanan ASI Perah. 2014. (Diakses pada 
tanggal 20 Juli 2017). Dapat diakses di http://www.idai.or.id/artikel/klinik/asi/penyimpana n-asi-perah

7. Rollo DE, Radmacher PG, Turcu1 RM, Myers $\mathrm{SR}$, Adamkin $\mathrm{DH}$. Stability of Lactoferrin in Stored Human Milk. Journal of Perinatology. 2014. hlm 1-3

8. Akinbi H, Derr JM, Auer C, Ma Y, Pullum D, Kusano R. et al. Alterations in the Host Defense Properties of Human Milk Following Prolonged Storage or Pasteurization. Journal of Pediatric Gastroenterology and Nutrition. 2010;51 (3). hlm 347-352

9. Chang JC, Chen $\mathrm{CH}$, Fang LJ, Tsai CR, Chan YC, Wang TM. Influence of Prolonged Storage Process, Pasteurization, and Heat Treatment on Biologically-active Human Milk Proteins. Pediatrics and Neonatology. 2013;54. hlm 360-366

10. Rahayu WP, Nurwitri CC. Mikrobiologi Pangan. Bogor: IPB Press; 2012. hlm 18-93

11. Fernandez L, Langa S, Martín V, Maldonado A, Jimenez E, Martin et al. The human milk microbiota: Origin and potential roles in health and disease. Pharmacological Research 2013;69. hlm 1-10

12. Estiasih T, Ahmadi K. Teknologi Pengolahan Pangan. Jakarta: Penerbit Bumi Aksara; 2011. hlm 130-276

13. Raoof NA, Adamkin DH, Radmacher PG, Telang $\mathrm{S}$. Comparison of lactoferrin activity in fresh and stored human milk. Journal of Perinatology. 2016;36. hlm 207-209.

14. Slutzah M, Codipilly CN, Potak D, Clark RM, Schanler RJ. Refrigerator Storage of Expressed Human Milk in the Neonatal Intensive Care Unit. The Journal of Pediatrics. 2010; 156(1). hlm 26-28

15. Buckle KA, Edwards RA, Fleet GH, Wootton M. Ilmu Pangan. Jakarta: UI Press; 2009. hlm 149-282

16. Siahaya GC. Pengaruh Lama Penyimpanan Air Susu Ibu (ASI) pada Suhu $-15^{\circ} \mathrm{C}$ terhadap Kualitas ASI. Jurnal 2-TRIK: Tunas-Tunas Riset Kesehatan. 2017;7(1). hlm 23-33

17. Murti TW. Pangan, Gizi, dan Teknologi Susu. Yogyakarta. Gadjah Mada University Press; 2014. hlm 26-81

18. Sari IP. Efek Lama Penyimpanan ASI terhadap Kadar Protein dan Lemak yang Terkandung di dalam AS. (Tesis). Padang: Universitas Andalas; 2015.

19. Lawrence R, Lawrence RM. Breastfeeding, A Guide for the Medical Profession, $7^{\text {th }}$ Edition. USA: Elsevier; 2011. hIm 169-717

20. Fogleman AD. Effect of Storage Time and Temperature on Components in Human Breast Milk (Thesis). North Carolina State. North Carolina State University; 2008.
21. Benkerroum N. Antimicrobial activity of lysozyme with special relevance to milk. African sJournal of Biotechnology. 2008;7 (25). hlm 4856-4867 